\section{The Australian Polarographic Society}

The Australian Polarographic Society was founded at the inaugural meeting held at the University of New South Wales on December 3, when the relative merits of an electrochemical and of a polarographic society were discussod. It was agreed that the initial viability of the Society would bo enhanced by concentrating the endeavour in such a way that the activities would tend to be of immediate interest to the great majority of members. On this basis, the foundation of a Polarographic Society was proforable at this stage. At a later time, whon the Society had proved its viability and value, the prospects for an Electrochemical Society could be reassessed. The objective of the Socioty is: "To promote the development of polarography in Australia by affording opportunitios for contact between thoso interested in polarography and related fields and by any other means that the Society shall from time to time determine". A Provisional Council has been elected: President, Prof. B. Breyer; VicePresident, G. S. Buchanan; Secretary-Treasurer, J. W. Hayes; Councillors, G. H. Aylward, Dr. H. H. Bauor and T. M. Florence. State Representatives are to be co-opted from each State/Territory. Membership is open "to all persons interested in furthering the aims of the Society"; details are available from the secretarytreasurer, Department of Analytical Chemistry, University of New South Wales, Box 1, P.O. Kensington.

\section{The Institute of Mathematical Sciences, Madras}

ON the occasion of the first anniversary of the Institute of Mathematical Sciences, Madras, announcements were made of two annual visiting professorships entitled: (1) the Niols Bohr visiting professorship; (2) the Ramanujam visiting professorship. The first is a tribute to the memory of one of the creators of modern physics and that of the founder of quantum theory. His interest in the advancement of science in India and in particular the work of the young group of theoretical physicists at Madras was the immediate stimulus for the ereation of this Institute. The second professorship is in memory of the Indian mathematician Dr. Srinivasa Ramanujam. Prof. R. E. Marshak, chairman of the Department of Physics and Astronomy, University of Rochester, New York, has accepted the first Niels Bohr professorship in February 1963. The award of the Ramanujam visiting professorship for this year will be announced later.

\section{Sixth International Symposium on Free Radicals}

THe sixth International Symposium on Free Radicals will be held at the University Chemical Laboratories, Lensfield Road, Cambridge, England, during July 2-5. Papers will be presented by authors from ten countries. The plenary lectures will be given by Dr. R. Livingston (United States), Dr. G. Wilse Robinson (United States) and Prof. J. Weiss (Great Britain). Following the tradition of theso meetings, the emphasis will again be on the preparation and properties of trapped radicals, including fluorescence, ultra-violet and electron spin resonance spectra, structural studies and many aspects of reaction kinetics. In addition to the formal sessions, a full programme of social events has been organized, including special entertainment for wives and friends of participants. The symposium will commence with an introductory lecture on the afternoon of July 2 , followed by a reception at the Guildhall. Accommodation for men and women will be available in the colleges of the University. Further information can be obtained from Dr. A. B. Callear, Department of Physical Chemistry, Lensfield, Cambridge.

\section{Eleventh International Congress of Applied Mechanics}

THE eleventh International Congress of Applied Mechanics will be held in the Deutsches Museum at Munich (Germany) during August 30-September 5, 1964. Apart from a number of invited goneral lectures, the technical sessions of the Congress will be held in two sections: Section 1, mechanies of solids; Section 2, mechanics of fluids and gases. The Congress will, however, not include thermodynamics or numerical mothods and computing machinos, with the exception of specific applications to pertinent problems of one of the two sections montioned abovo. Thoso porsons wishing to present papers to the Congress should submit them to the Programm-Sekretariat des Mechanik-Kongresses, Stuttgart (Germany), Technische Hochschule, Institut für Mechanik, before February 1, 1964 (except that by arrangemont with the U.S. National Committee on Theoretical and Appliod Mechanics, contributions from the United States will be by invitation, and likewise with the exception of papers submitted by the authors from the U.S.S.R., for which a special arrangement has been made with the U.S.S.R. National Committee on Theoretical and Applied Mechanies). Further information can be obtained from the Organisations-Secretariat des Mochanik-Kongresses, München 2 (Germany), Institut für Mechanik, Arcisstrasse 21.

\section{Naturally Occurring Peptides, Peptide Antibiotics,}

Proteins and Nucleoproteins

Prof. K. T. Yasunobu and L. K. Ramachandran have written to the Editor stating that they aro compiling data on the physical, chemical, functional and structural properties of: (a) naturally occurring peptides; $(b)$ proteins and nucleoproteins; (c) enzymes. They anticipate eventual publication of the data in the form of a book, and ask for any pertinent data to be forwarded for them at the Department of Biochemistry and Biophysics. University of Hawaii, Honolulu, Hawaii.

\section{Announcements}

Dr. T. H. Benzinger, director of the Bio-Energetics Laboratories of the Naval Medical Research Institute. National Naval Medical Center, Bethesda, has been awarded the Golden Scheele Medal of the Chemical Society of Stockholm, for his work on "Calorimetric Analysis of Chemical Change".

THE sixth International Mineral Processing Congress will bo held in Cannos during May 26-June 2. Further information can be obtained from the Sixth International Mineral Processing Congress, 28 ruo Arthur-Rozior. Paris XIXe.

A conference on "Inert Gas Compounds" will be held at Argonne National Laboratory during April 22-23. Further information can be obtained from Herbert $\mathrm{H}$. Hyman, Argonne National Laboratory, 9700 South Cass Avenue, Argonne, Illinois.

THE fifth International Conference on Coal Science will be held in Cheltenham, Gloucestershire, during May 28-30. Further information can be obtained from Mr. R. G. J. Kingsmill, National Coal Board Research Establishment, Stoke Orchard, near Cheltenham, Gloucestershire.

The South African National Conference on Nuclear Energy will be held in Pretoria during April 8-11. The main object of the meoting is to make a survey of isotopes and radiation research in South Africa and its future. Further information can be obtainod from the Atomic Energy Board, Post Bag 256, Pretoria.

AN international symposium on "Humidity and Moisture-Measurement and Control in Science and Industry", sponsored by the National Bureau of Standards, the United States Weather Bureau, the Instrument Socioty of America, the American Meteorological Society and the American Society of Heating, Refrigerating and Air Conditioning Enginoors, is to be held in Washington during May 20-23. Further information can be obtainesd from Mr. A. Wexler, National Bureau of Standardis, Washington 25, D.C. 